International Journal of Zoological Investigations

Contents available at Journals Home Page: www.ijzi.net

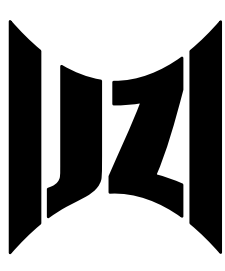

ISSN: 2454-3055

\title{
Comparative Toxicity of Copper Oxide Nanoparticles and Dissolved Copper to Freshwater Mussels
}

\author{
Auclair J., Turcotte P., Gagnon C., Peyrot C., Wilkinson KJ and Gagné F.* \\ Aquatic Contaminants Research Division, Environment and Climate Change Canada, 105 McGill, Montréal, Québec, Canada H2Y \\ 2E7 \\ ${ }^{*}$ Corresponding Author
}

Received: 25th March, 2020

Accepted: $18^{\text {th }}$ April, 2020

Published online: $7^{\text {th }}$ May, 2020

https://doi.org/10.33745/ijzi.2020.v06i01.011

\begin{abstract}
The commercial use of copper oxide nanoparticles (nCu0) has raised concerns about the toxic risk to filter feeders such as bivalves. The purpose of this study was to compare the toxicity of $\mathrm{nCuO}$ and dissolved $\mathrm{Cu}^{2+}$ to the freshwater mussel Dreissena bugensis. Mussels were exposed to a range of concentrations of both forms of $\mathrm{Cu}(2$, 10 and $50 \mu \mathrm{g} / \mathrm{L}$ ) for $96 \mathrm{~h}$ at $15 \mathrm{C}$. After the exposure period, some mussels were kept aside to determine the air survival time as a measure of resistance to stress. The remaining mussels were processed for total and labile $\mathrm{Cu}$ determination in their tissues and the following effects: lipid peroxidation (LPO), DNA damage, arachidonate cyclooxygenase (COX), protein-ubiquitin levels (UB), acetylcholinesterase (AChE) and glutathione S-transferase (GST) activity. The data revealed that only exposure to $\mathrm{Cu}^{2+}$ led to the accumulation of total $\mathrm{Cu}$ in tissues with a decrease in labile $\mathrm{Cu}^{2+}$ levels suggesting that $\mathrm{Cu}$ was strongly bound to tissues. Exposure to $\mathrm{nCuO}$ led to specific effects on COX activity (inflammation) and UB levels (damaged protein turnover). It is concluded that although no significant changes in $\mathrm{Cu}$ levels in mussels were detected, exposure to $\mathrm{nCuO}$ produced different effects than $\mathrm{Cu}^{2+}$ in freshwater mussels.
\end{abstract}

Keywords: Nanoparticle, Copper Oxide, Bioaccumulation, Oxidative stress, Inflammation, Protein damage, Toxicity, Freshwater mussel

Citation: Auclair J., Turcotte P., Gagnon C., Peyrot C., Wilkinson KJ and Gagné F.: Comparative toxicity of copper oxide nanoparticles and dissolved copper to freshwater mussels. Intern. J. Zool. Invest. 6 (1): 135-147, 2020. https://doi.org/10.33745/ijzi.2020.v06i01.011

\section{Introduction}

Nanotechnology is a rapid growing field with many applications in many key areas of our economy. They have application in diverse area such as medical diagnostics, therapeutics, electronics and personal care products. Nanotechnology produce materials that display at least one dimension in the nanoscale at size range between 1-100 $\mathrm{nm}$. 
The increasing commercial activities of these products could lead to the inadvertent release in the aquatic environment and threaten aquatic life (Rather et al., 2018). The unique properties of nanoparticles such as size, surface area, and surface coating and charge could influence the fate, bioavailability across different tissues and toxicity in aquatic organisms. Copper oxide nanoparticles (nCuO) are particularly of concern given their multiple uses in our economy (Raiput et al., 2020). At the nanoscale, $\mathrm{nCuO}$ is increasingly used as bioactive paints, integrated circuits, batteries, and for liquid/air filtration. They also have interesting bactericidal properties and are added in skin care products and clothes. More research is needed to better understand the fate of $\mathrm{nCuO}$ in the environment, bioavailability and toxicity mechanisms especially if $\mathrm{nCuO}$ will degrade and release $\mathrm{Cu}^{2+}$ ions and contribute to toxicity. The identification of key physiological targets that respond to $\mathrm{nCuO}$ and $\mathrm{Cu}^{2+}$ is of interest. Indeed, the better understanding of the mechanisms of nanoparticle toxicity is crucial in risk assessment since conventional toxicity tests (i.e, using ionic $\mathrm{Cu}$ ) may not answer the above questions.

Ionic $\mathrm{Cu}^{2+}$ and $\mathrm{Cu}^{1+}$ are biological essential metals and are found in reaction centres of many enzymes involved in redox reactions such as superoxide dismutase and cytochrome c oxidase. $\mathrm{Cu}$ could become toxic when present at concentrations that overwhelms storage capacity and regulatory mechanisms in cells. Indeed, $\mathrm{Cu}$ is not usually found in its free ionic form because it is strongly bound to thiol-containing proteins such as metallothioneins and glutathione which are considered as storage pools of $\mathrm{Cu}$ (Amiard et al., 2006). Bivalves are especially at risk to nanoparticles given their filtering activity where they can trap important quantities of suspended materials including nanoparticles and their aggregates. They are also sessile and live for relatively long periods, which makes them targets to nanotechnology pollution. This is in keeping with bivalves are considered relevant organisms towards potentially toxic compounds associated to dissolved solids and colloids (Gagné et al., 2007; Canesi et al., 2012). Exposure of mussels to $\mathrm{Cu}^{2+}$ and $\mathrm{nCuO}$ revealed uptake in tissues when exposed at relatively high concentrations in mg/L range (Hanna et al., 2014). The toxicity of $\mathrm{Cu}$ involves protein and DNA damage from oxidative stress and altered immune responses in mussels (Hu et al., 2014). Nanoparticles also produce reactive oxygen species and oxidative stress, which is considered as one of the major toxic effects although these are not always explained by dissolved $\mathrm{Cu}^{2+}$. This suggests that toxicity also results from other properties such as size, surface charge, reactivity and corona properties (Gagné et al., 2007; Duran et al., 2015). Recent investigations revealed that nanoparticles could induce inflammation from ingested particles and protein denaturation and turnover (Gagné et al. 2012; Hu et al., 2014). However, it is not known whether inflammation and protein turnover were related or were the results from independent pathways. The origin of oxidative stress (i.e., from release of $\mathrm{Cu}^{2+}$ or inflammation) also needs further investigations. In this respect, the identification of specific toxic effects that could discriminate between $\mathrm{nCuO}$ and dissolved $\mathrm{Cu}^{2+}$ would be of value for the risk assessment and management of Cu-based products in order to track their effects in the environment. 
The purpose of this study was therefore to examine and compare the toxicity of $\mathrm{nCuO}$ and $\mathrm{Cu}^{2+}$ to quagga mussel Dreissena bugensis. Toxicity was examined by following changes in oxidative stress (glutathione S-transferase and lipid peroxidation), inflammation (arachidonate cyclooxygenase), genotoxicity (DNA stand breaks), protein turnover (ubiquitin tagging to proteins) and neuromuscular activity by following acetylcholinesterase (AChE) activity. The null hypothesis consists in the statement that the toxicity of $\mathrm{nCuO}$ and $\mathrm{Cu}^{2+}$ is the same. An attempt was made to identify biomarkers that could discriminate between the effects of each $\mathrm{Cu}$ forms.

\section{Materials and Methods}

\section{Copper oxide nanoparticle:}

A stock solution of Copper oxide nanoparticle (nCuO) was obtained from US Research Materials (USA). This commercial $\mathrm{nCuO}$ suspension composed nanoparticles in the 25$55 \mathrm{~nm}$ diameter size range according to the supplier information that was confirmed Dynamic Light Scattering analysis as described below. For the exposure regime, quagga mussels (Dreissena bugensis) were exposed to increasing concentrations of either $\mathrm{nCuO}$ or $\mathrm{Cu}^{2+}$ as $\mathrm{CuSO}_{4}$ in dechlorinated tap water (controls): $0,2,10$ and $50 \mu \mathrm{g} / \mathrm{L}$ as total $\mathrm{Cu}$. Controls consisted of aquarium water which was obtained from tap water from the city of Montreal after additional UV-treatment and charcoal filtration. The nanoparticle's size and Zeta potential of $\mathrm{nCuO}$ were determined in aquarium water using a dynamic light scattering instrument (Mobius Instrument, Wyatt Technologies, Santa Barbara, CA, USA) operating with a laser at a wavelength of 532 $\mathrm{nm}$. The instrument was previously calibrated with standard suspensions of latex nanoparticles (Polyscience, USA).

The total levels of Cuin the exposure media were determined after $1 \mathrm{hr}$ of dissolution of nCuO using ICP-MS spectrometry following acidification with $1 \% \mathrm{v} / \mathrm{v}$ nitric acid (Seastar grade $\mathrm{BC}$, Canada). Quagga mussels $(\mathrm{n}=20)$ were exposed to either $\mathrm{nCuO}$ or $\mathrm{Cu}^{2+}$ as $\mathrm{CuSO}_{4}$ for $96 \mathrm{~h}$ at $15 \mathrm{C}$ under constant aeration. The exposure media were not renewed and the mussels were not fed during that time. After the exposure period, mussel mortality was checked and a subgroup of mussels $(\mathrm{N}=10)$ were kept aside for air-time survival assessment. For total $\mathrm{Cu}$ levels in mussels, a subgroup of 20 individuals were placed in clean aquarium water overnight as a depuration step and the mussels were removed for total $\mathrm{Cu}$ determination using ICPmass spectrometry as described above. The tissues were first acid-digested with concentrated $\mathrm{HNO}_{3}, \mathrm{HCl}$ and $30 \% \mathrm{H}_{2} \mathrm{O}_{2}$, then heat-digested in microwave vessels for $2 \mathrm{~h}$ and diluted with MilliQ water to a volume of $12 \mathrm{~mL}$. For the biomarker analyses, the remaining group of 10 mussels were analyzed for total weight shell length, total and soft tissues weights. The soft tissues were quickly stored at $-85 \mathrm{C}$ with 5 volumes of homogenization buffer. The homogenization buffer consisted of $50 \mathrm{mM} \mathrm{NaCl}$ containing 2 $\mathrm{mM} \mathrm{KH} \mathrm{PO}_{4}, 1 \mathrm{mM} \mathrm{NaHCO} 3,25 \mathrm{mM}$ Hepes$\mathrm{NaOH}, \mathrm{pH} 7.4,1 \mu \mathrm{g} / \mathrm{mL}$ apoprotininand $1 \mathrm{mM}$ dithiothreitol.

Air survival test:

After the exposure period, 10 mussels were kept aside to determine the air-time survival as previously described (Gagné et al., 2015). Briefly, mussels were randomly chosen and 
placed individually into plastic plates under $80 \%$ humidity at $18 \mathrm{C}$. They were maintained as such and weighed each day until mortality was determined by shell opening. The time of death in days was determined for each individual over the 7 treatment groups: 1 control, $3 \mathrm{nCuO}$ concentrations and $3 \mathrm{Cu}^{2+}$ concentrations. The weight loss during air emersion at day 3 (the last day before manifestation of mortality) was also measured and the data were expressed as the ratio of weight loss (weight at given day/initial weight)

\section{Biomarker assessments:}

The soft tissues were allowed to thaw on ice for 15-20 $\mathrm{min}$ and homogenized still in melting ice using a Teflon pestle tissue grinder at $4 \mathrm{C}$. A portion of the homogenate was set aside for lipid peroxidation (LPO), DNA damage and total proteins. The remainder of the homogenate was centrifuged at $15000 \mathrm{x} \mathrm{g}$ for $20 \mathrm{~min}$ at $4 \mathrm{C}$ and the supernatant (S15) was removed for arachidonate cyclooxygenase (COX), glutathione Stransferase (GST), acetylcholinesterase (AChE), labile $\mathrm{Cu}^{2+}$ and protein-ubiquitin level evaluations. Total proteins were determined in the homogenate and S15 fraction using the protein-dye binding principle using standard solutions of serum bovine albumin for calibration (Bradford, 1976).

Lipid peroxidation (LPO) was determined in soft tissue homogenates using the thiobarbituric acid method (Wills, 1987). A volume of $10 \mu \mathrm{L}$ of the homogenate was mixed with $175 \mu \mathrm{L}$ of $10 \%$ trichloroacetic acid containing $1 \mathrm{mM} \mathrm{FeSO}_{4}$ and $50 \mu \mathrm{L}$ of $0.7 \%$ thiobarbituric acid. The mixture was heated at $75 \mathrm{C}$ for $10 \mathrm{~min}$. The mixture was cooled to room temperature and centrifuged at $10000 \mathrm{x}$ $\mathrm{g}$ for $5 \mathrm{~min}$ to remove any precipitates. A 150 $\mu \mathrm{L}$ volume was transferred to a 96-well dark microplate, and fluorescence readings were taken at $540 \mathrm{~nm}$ excitation and $590 \mathrm{~nm}$ emission. Standard solutions of malonaldehyde (tetramethoxypropane, Sigma Chemical Company, ON, Canada) were prepared for calibration. Results were expressed as $\mu \mathrm{g}$ thiobarbituric acid reactants (TBARS)/mg total proteins in the homogenate. The levels of DNA strand breaks were also determined in the homogenate using the fluorescence DNA precipitation assay (Olive, 1988; Gagné et al., 2008). Briefly, $20 \mu \mathrm{L}$ of the homogenate from each tissues were mixed with $100 \mu \mathrm{L}$ of $50 \mathrm{mM} \mathrm{NaOH}, 10$ $\mathrm{mM}$ Tris base, $10 \mathrm{mM}$ ethylenediamine tetraacetate and 2\% sodium dodecyl sulphate (SDS) for $5 \mathrm{~min}$ and $120 \mu \mathrm{L}$ of $0.12 \mathrm{M} \mathrm{KCl}$ was added. The mixture was heated at $60 \mathrm{C}$ for 10 $\mathrm{min}$, cooled on ice for $5 \mathrm{~min}$ and centrifuged at $8000 \mathrm{x} \mathrm{g}$ for $10 \mathrm{~min}$ to precipitate SDSassociated protein and genomic DNA. The supernatant (DNA strands) was mixed with SYTO Green dye in $3 \mathrm{mM}$ sodium cholate, 0.4 $\mathrm{M} \mathrm{NaCl}$ and $100 \mathrm{mM}$ Tris-acetate $\mathrm{pH} 8$ to control for the traces of SDS in the supernatant which could interference with fluorescence readings (Bester et al., 1994). Fluorescence was measured at $485 \mathrm{~nm}$ excitation and $530 \mathrm{~nm}$ emission (Microplate, Synergy-4, Bioteck, USA) using standard solutions of salmon sperm DNA for calibration. The data were expressed as $\mu \mathrm{g}$ supernatant DNA/mg proteins.

Levels of labile $\mathrm{Cu}^{2+}$ were determined using a fluorescent probe methodology (Udhayakumaria et al., 2014). A $20 \mu \mathrm{L}$ sample of the S15 fraction was mixed with $180 \mu \mathrm{L}$ of $50 \mu \mathrm{M}$ of 1,2-diaminoanthraquinone in 100 


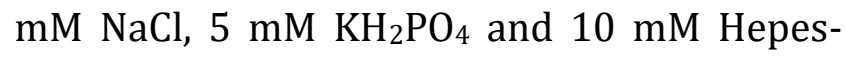
$\mathrm{NaOH}, \mathrm{pH}$ 7.4. Fluorescence was measured at $400 \mathrm{~nm}$ excitation and $475 \mathrm{~nm}$ emission (Synergy-4, Biotek Instuments, USA) using standard solutions of $\mathrm{CuSO}_{4}$ for instrument calibration. Data were expressed as relative fluorescence units (RFU)/mg proteins. The activity of arachidonate-dependent cyclooxygenase (COX) activity was determined in the S15 fraction of soft tissues using a fluorescence microplate reader (Gagné, 2014). The S15 fraction was mixed with $50 \mu \mathrm{M}$ arachidonate, $2 \mu \mathrm{M}$ of dichlrofluorescein and $0.1 \mu \mathrm{g} / \mathrm{mL}$ of horseradish peroxidase in $50 \mathrm{mM}$ Tris- $\mathrm{HCl}$, pH 8.0 and $0.05 \%$ Tween- 20 for 20 min at 20 $\mathrm{C}$ in dark microplates. Fluorescence measurements at each 5-min were taken at $485 \mathrm{~nm}$ excitation and $528 \mathrm{~nm}$ emission (Synergy 4, Biotek Instruments, USA). The data were expressed as the increase in relative fluorescence units $/ \mathrm{min} / \mathrm{mg}$ proteins in the S15 fraction. Acetylcholinesterase (AChE) activity was determined in the S15 fraction using acetylthiocholine as the substrate analogue for acetylcholine. The formation of thiocholine were determined using the Ellman's reagent according to Gélinas et al. (2013). Standard solutions of reduced glutathione were used for calibration. The data were expressed as absorbance increase at $412 \mathrm{~nm} / \mathrm{min} / \mathrm{mg}$ proteins. The activity of glutathione S-transferase (GST) activity were determined in the S15 fraction using a microplate spectrometric assay (Boryslawskyj et al., 1988). The activity was determined using reduced glutathione and 2,4-dichlorodinitro-benzene as the chromophore substrate at $340 \mathrm{~nm}$. The data were expressed as the increase in absorbance at $340 \mathrm{~nm} / \mathrm{min} / \mathrm{mg}$ total proteins in the $\mathrm{S} 15$ fraction. The levels of polyubiquitinylated proteins were determined by enzyme-linked immuno-sorbent assay (ELISA) in the S15 fraction as described in a previous study (Auclair et al., 2019). Standards of polyubiquitin (Ub2-7, K48-linked, Enzo Life Sciences, Farmingdale, NY) or the S15 fraction were used to coat the microplate wells (Immulon-4). The antibody ubiquitin lys48specific rabbit monoclonal antibody (clone Apu2; EMD Millipore, Billerica, USA) was diluted $1 / 2000$ in phosphate buffered saline $\left(140 \mathrm{mM} \mathrm{NaCl}, 5 \mathrm{mM} \mathrm{KH}_{2} \mathrm{PO}_{4}\right.$ and $1 \mathrm{mM}$ $\mathrm{NaHCO}_{3}, \mathrm{pH}$ 7.4) containing $0.5 \%$ albumin and was added to each wells. After incubation for $60 \mathrm{~min}$, the wells were washed with $0.5 \%$ albumin and the secondary antibody (antirabbit Igg-linked with to peroxidase; ADI-SAB300, Enzo, USA) diluted 1/5000 and incubated for another hour. After well washing, the activity of peroxidase was detected using a highly sensitive Chemiluminescence assay kit (Roche Diagnostics, QC, Canada). Data were expressed as ng of polyubiquitin/mg proteins.

\section{Data analysis:}

The study design examines the bioavailability and toxicity of $\mathrm{nCuO}$ and $\mathrm{Cu}^{2+}$ in quagga mussels where the null hypothesis is that the bioavailability and toxicity of both forms of $\mathrm{Cu}$ are identical. In this study, there were in total 7 treatments: mussels exposed to aquarium water only (controls); mussels exposed to 3 concentrations $\mathrm{Cu}$ as $\mathrm{nCuO}$ in aquarium water; and mussels exposed to 3 concentrations of $\mathrm{Cu}$ as $\mathrm{CuSO}_{4}$ in aquarium water. Data normality and homogeneity of variance were determined using the Shapiro-Wilk and Bartlett tests, respectively. The influence of exposure concentration and $\mathrm{Cu}$ forms (control, $\mathrm{nCuO}$ and $\mathrm{Cu}^{2+}$ ) were examined using 
2-way factorial analysis of variance. Critical differences between treatments were determined using the Least Square Difference (LSD) test. The trends between the data were also analyzed using the Pearson moment correlation test. The biomarker data were also analyzed by discriminant function analysis to determine which biomarkers best discriminate between the forms of $\mathrm{Cu}$. Significance was set at $p<0.05$. All statistical analyses were performed with the SyStat software package (version 13.2, USA).

\section{Results}

The levels of $\mathrm{Cu}$ in solution were determined in the aquarium water after $1 \mathrm{~h}$ of dissolution of $\mathrm{nCuO}$ (Table 1). For $\mathrm{nCuO}, 90 \%$ of $\mathrm{Cu}$ was detected in the MilliQ water with a mean diameter of $79 \mathrm{~nm}$ with a Zeta potential of -15 mvolts. In the aquarium water, $70 \%$ of the $\mathrm{Cu}$ was detected with no changes in the mean diameter and Zeta potential for nCuO. The mussel weigth/shell length and soft tissues ratios were not significantly affected by either $\mathrm{Cu}^{2+}$ and $\mathrm{nCuO}$ (data not shown). The same was observed for air-time survival and weight loss after 4 days suggesting that no important systemic effects and survival was caused by exposure to $2-50 \mu \mathrm{g} / \mathrm{L}$ total $\mathrm{Cu}$ as either $\mathrm{Cu}^{2+}$ and $\mathrm{nCuO}$. Air-time survival was significantly correlated with weight loss at day 4 ( $\mathrm{r}=-0.59)$ indicating a stronger initial weight loss at the third day was associated with lower air survival time in the mussel samples. The levels of total $\mathrm{Cu}$ and labile $\mathrm{Cu}^{2+}$ were determined in soft tissues in mussels exposed to each $\mathrm{Cu}$ forms (Fig. 1). For total $\mathrm{Cu}$ in soft tissues, the levels changed over the exposure concentrations used (ANOVA $\mathrm{p}<0.01$ ). The total $\mathrm{Cu}$ levels were significantly increased in mussels exposed to dissolved $\mathrm{Cu}^{2+}$ at 10 and $50 \mu \mathrm{g} / \mathrm{L} \mathrm{Cu}$ compared to controls. Cu levels were also significantly higher in the $10 \mu \mathrm{g} / \mathrm{L}$ $\mathrm{Cu}^{2+}$ group compared to the $10 \mu \mathrm{g} / \mathrm{L} \mathrm{nCuO}$ group. For labile $\mathrm{Cu}$ levels, the only significant effect was a decrease in labile $\mathrm{Cu}$ in gills in mussels exposed to $50 \mathrm{ug} / \mathrm{L}$ of $\mathrm{Cu}^{2+}$.

Oxidative stress and inflammation were examined in mussels exposed to each forms of $\mathrm{Cu}$ by following changes in GST and COX activities, respectively (Fig. 2). GST activity was not significantly changed by exposure concentrations and $\mathrm{Cu}$ forms (2-way factorial ANOVA $\mathrm{p}>0.05$ for concentration and $\mathrm{Cu}$ forms). COX activity was significantly influenced by concentrations and forms of $\mathrm{Cu}$ as determined by 2-way ANOVA. COX activity was higher in mussels exposed to $10 \mu \mathrm{g} / \mathrm{L}$ $\mathrm{nCuO}$ compared to controls or to $10 \mathrm{ug} / \mathrm{L} \mathrm{Cu}^{2+}$ group. GST activity was significantly correlated with soft tissues ratio $(\mathrm{r}=-0.30)$ and LPO levels with COX activity ( $\mathrm{r}=-0.32$ ).

Table 1: Physico-chemical properties of nCuO in the exposure media

\begin{tabular}{|c|c|c|}
\hline Parameter & MilliQ water & $\begin{array}{c}\text { Aquarium } \\
\text { water }\end{array}$ \\
\hline Cu concentration & $\begin{array}{c}200 \mathrm{ug} / \mathrm{L} \\
(\mathrm{nCuO})\end{array}$ & $\begin{array}{c}200 \mathrm{ug} / \mathrm{L} \\
(\mathrm{nCuO})\end{array}$ \\
\hline$\%$ remaining & $90 \%$ & $70 \%$ \\
\hline $\begin{array}{c}\text { Mean diameter } \\
(\mathrm{nm})\end{array}$ & $79 \pm 10$ & $74 \pm 5$ \\
\hline $\begin{array}{c}\text { Zeta potential } \\
\text { (mvolt) }\end{array}$ & $-15 \pm 5$ & $-13 \pm 3$ \\
\hline
\end{tabular}

Tissue damage was examined at the protein (polyubiquitinylation), lipids (LPO) and DNA levels (Fig. 3). Protein-ubiquitin level was significantly increased in mussels 


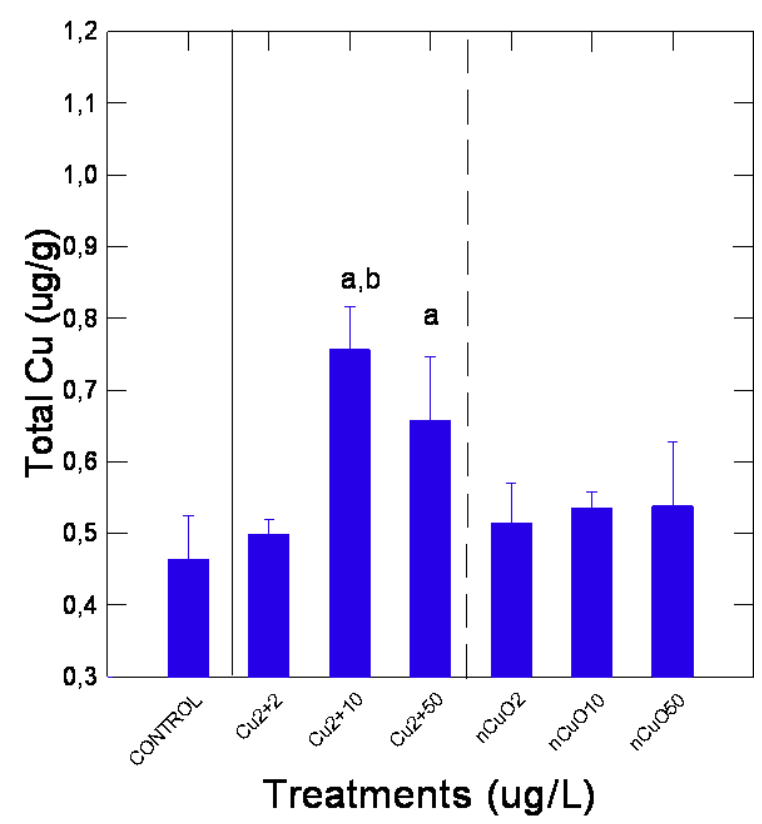

A

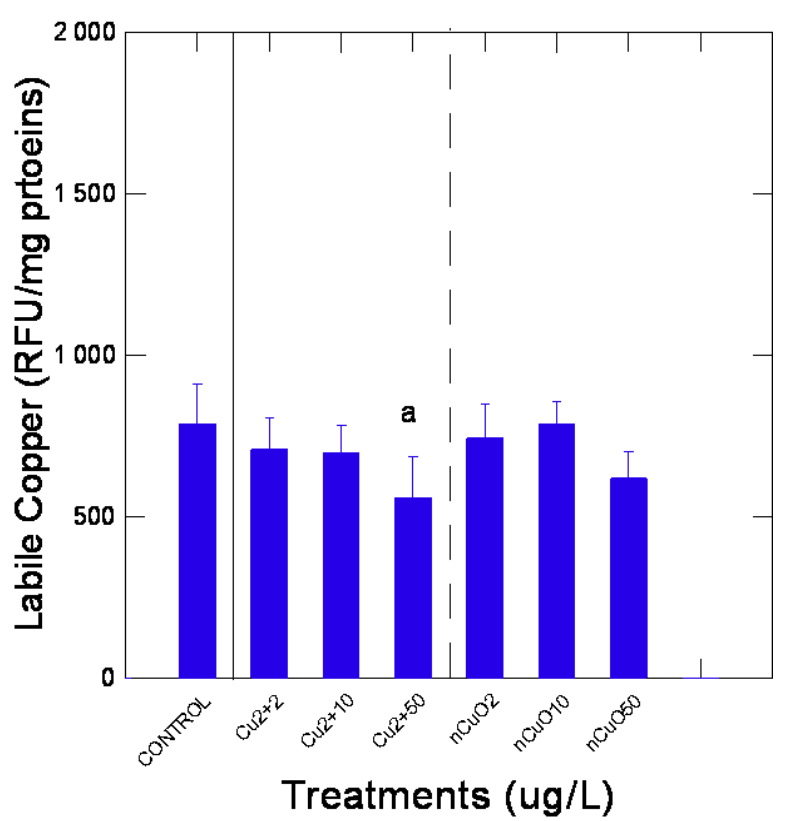

B

Fig. 1: Tissue levels of labile $\mathrm{Cu}^{2+}$ in mussels exposed to $\mathrm{nCuO}$ and dissolved $\mathrm{Cu}$. $\mathrm{a}$ and $\mathrm{b}$ indicate significance from control and between the forms of $\mathrm{Cu}$ (at the same concentrations).
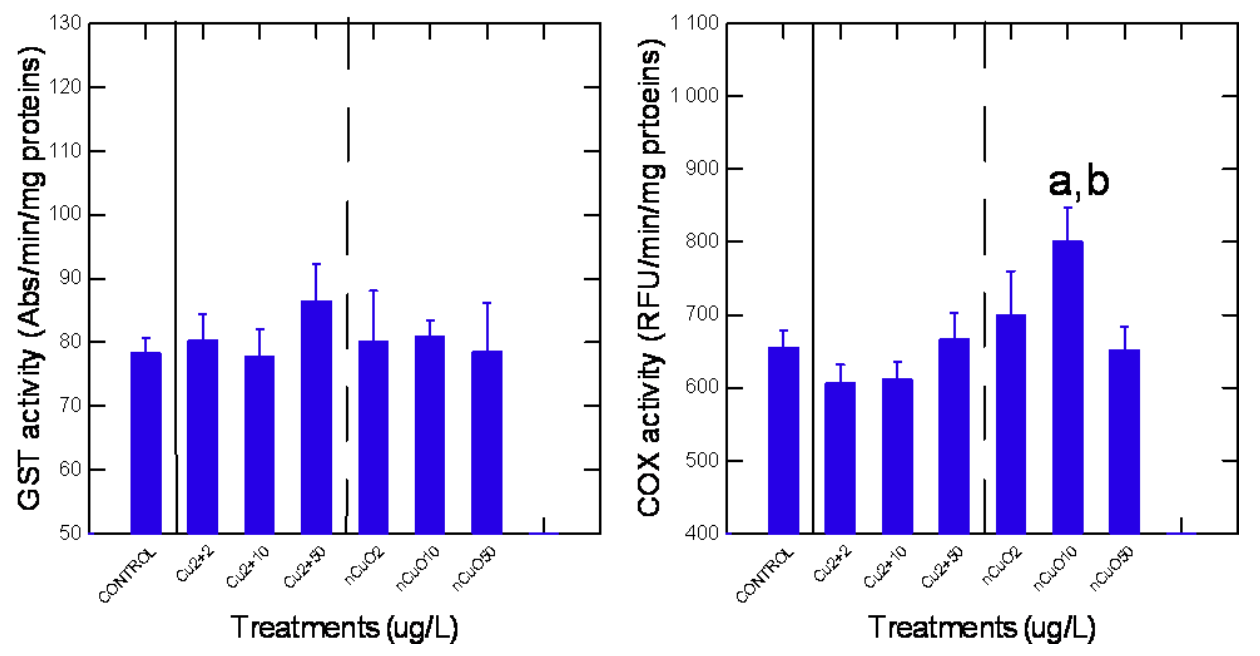

Fig. 2: Oxidative stress in mussels exposed to $\mathrm{Cu}$ forms.

$\mathrm{a}$ and $\mathrm{b}$ indicates significance from control and between the forms of $\mathrm{Cu}$ (at the same concentrations). 

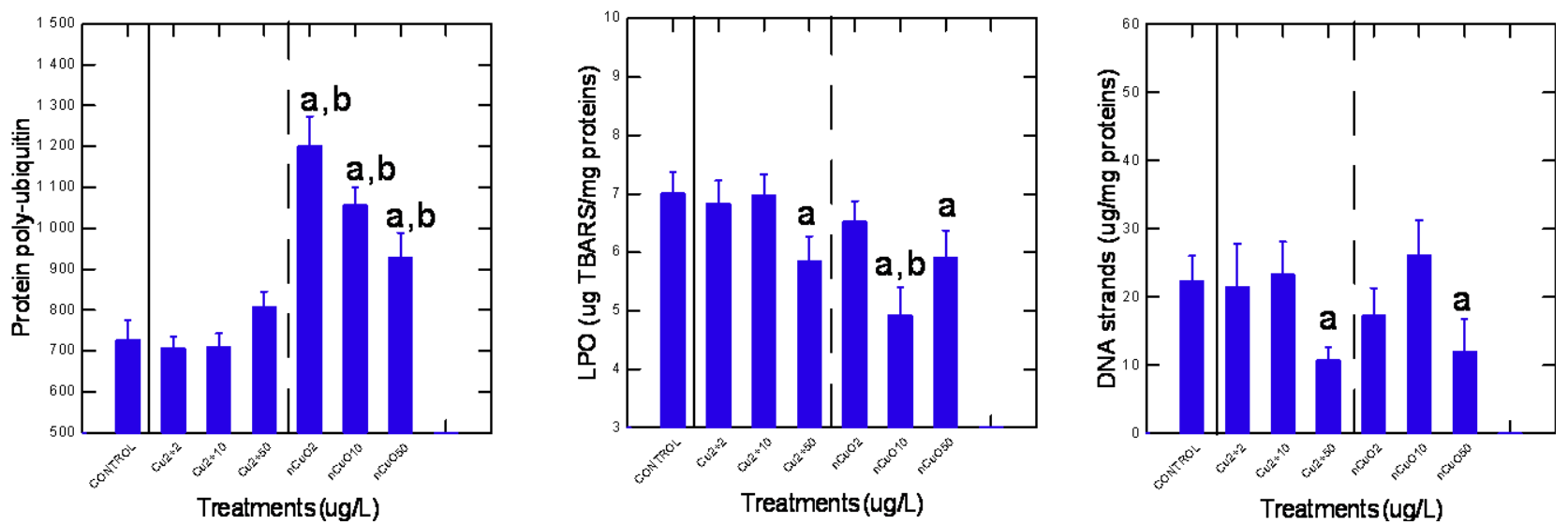

Fig. 3: Biomarker of tissue damage in mussels exposed to $\mathrm{Cu}$ forms.

Tissue damage was determined by following changes in poly-ubiquitinylated proteins, LPO and DNA damage. a and $\mathrm{b}$ indicates significance from control and between the forms of $\mathrm{Cu}$ (at the same concentrations).

exposed to $\mathrm{nCuO}$ only in respect to control or to the equivalent $\mathrm{Cu}^{2+}$ concentration. Protein ubiquitin levels were significantly correlated with Cox activitiy ( $\mathrm{r}=0.61)$. LPO levels were generally decreased by either dissolved or nanoparticulate $\mathrm{Cu}$ with $\mathrm{nCuO}$ decreasing LPO levels at lower concentrations than $\mathrm{Cu}^{2+}(10$ instead of $50 \mu \mathrm{g} / \mathrm{L}) . \quad \mathrm{Cu}$ levels were significantly correlated with LPO levels $(\mathrm{r}=0.48)$. The levels of DNA strand breaks were also determined in mussels treated to $\mathrm{Cu}$ forms and concentrations. DNA strand breaks were significantly decreased in mussels exposed to $50 \mu \mathrm{g} / \mathrm{L} \mathrm{Cu}^{2+}$ and $\mathrm{nCuO}$. DNA strand breaks were also significantly correlated with total $\mathrm{Cu}$ levels ( $\mathrm{r}=-0.34)$. The activity in AChE was also determined in mussels exposed to either forms of $\mathrm{Cu}$ concentrations (Fig. 4). AChE activity was significantly decreased in mussels exposed to 10 and $50 \mathrm{ug} / \mathrm{L} \mathrm{nCu}$ ). AChE activity was also somewhat decreased in the first 2 concentrations of dissolved $\mathrm{Cu}^{2+}$ compared to the controls but did not differed from $\mathrm{nCuO}$ at the corresponding concentrations. Correlation analysis revealed that AChE was significantly correlated with COX ( $\mathrm{r}=-34)$ and GST (0.59) activities.

Fig. 4: Change in acetylcholinesterase activity in mussels exposed to both forms of $\mathrm{Cu}$.

$a$ and $b$ indicates significance from control and between the forms of $\mathrm{Cu}$ (at the same concentrations).

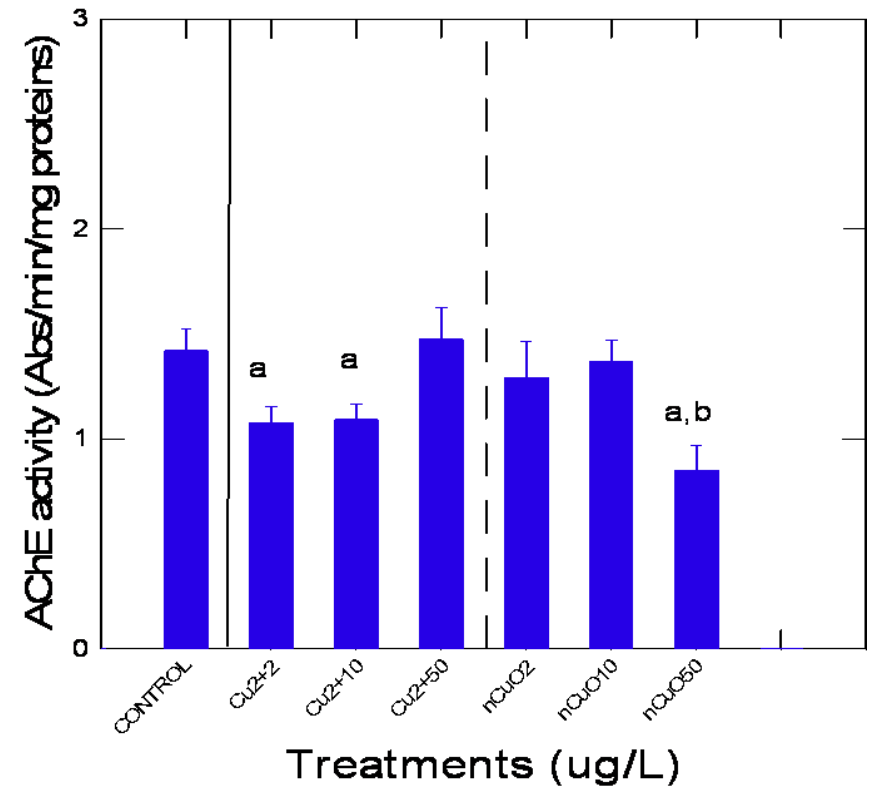

In the attempt to gain a global view on the mussels' response to each forms of $\mathrm{Cu}, \mathrm{a}$ discriminant function analysis was performed (Fig. 5). The analysis revealed that all the variance was explained with a mean classification performance of $92 \%$ indicating 


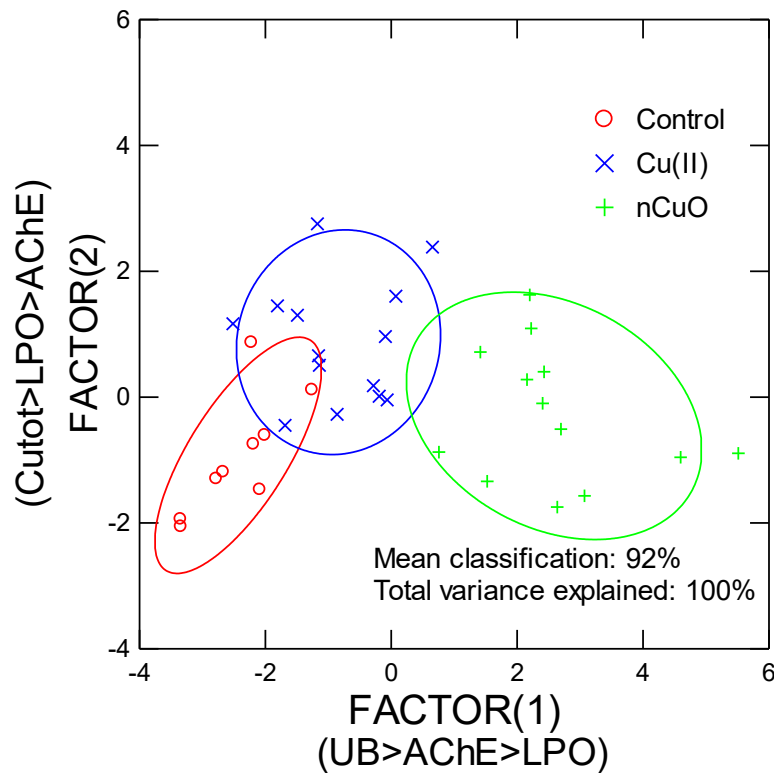

Fig. 5: Multivariate analysis of biomarker data. Discriminant function analysis was performed on the biomarker data. The effects from nCuO were discriminated (92\% classification; $100 \%$ of the variance explained) from the observed effects of $\mathrm{Cu}^{2+}$ and controls.

that the effects between controls, $\mathrm{Cu}^{2+}$ and nCuO could be discriminated with each other at the sublethal level. The biomarkers more closely associated were protein ubiquitin, AChE, LPO and total $\mathrm{Cu}$ levels in mussels. The effects between $\mathrm{nCuO}$ and $\mathrm{Cu}^{2+}$ were best separated by protein ubiquitin, AChE and LPO levels. Given that protein-ubiquitin levels were strongly correlated with COX activity $(\mathrm{r}=0.61)$, this activity was also able to respond more closely to $\mathrm{nCuO}$.

\section{Discussion}

Based on the $\mathrm{Cu}$ bioaccumulation data, the $\mathrm{Cu}$ loadings were significantly increased in mussels exposed to dissolved $\mathrm{Cu}^{2+}$ only. Mussels exposed to low concentrations of nCuO did not display significant $\mathrm{Cu}$ bioaccumulation in tissues. However, nCuO was reported as bioavailable on Swan mussels Anodonta cygnea exposed to 0.25, 2.5 and 25 ug/L as total $\mathrm{Cu}$ for 12 days (Moezzi et al.,
2019). The foot accumulated more $\mathrm{Cu}$ than the mantle with bioaccumulation factors of 5.4 and 3.25, respectively. Hence, the accumulation of $\mathrm{nCuO}$ in mussels could be related to the size, exposure time and species which prevent us to generalize bioavailabitly of $\mathrm{nCuO}$ with only one test species. Another factor is that tissue analyses were performed in the whole soft tissues (i.e., not in specific tissues) because of the small size of quagga mussels compared to Swan mussels. In another study with marine mussels exposed to $\mathrm{nCuO}$, mussels were able to ingest and effectively excrete the nanoparticles which could explain the lack of total $\mathrm{Cu}$ bioaccumulation in tissues when exposed to low concentrations of $\mathrm{nCuO}$ (Hanna et al., 2014). Notwithstanding this, exposure to a higher concentration of $3 \mathrm{mg} / \mathrm{L} \mathrm{nCuO} \mathrm{led} \mathrm{to}$ bioaccumulation factor of 26 . There were no changes in labile $\mathrm{Cu}^{2+}$ in mussels exposed to either forms of $\mathrm{Cu}$ suggesting that $\mathrm{Cu}$ was readily (strongly) bound in mussel tissues. $\mathrm{Cu}^{2+}$ binds strongly to thiol-containing proteins such as metallothioneins (MT) which is induced by divalent heavy metals (Farrell et al., 1993). However, if the induction of MT is sufficient to prevent the spill-over of $\mathrm{Cu}$ ions to the intracellular protein pool, the increase in labile $\mathrm{Cu}$ would be limited. Based on the present data, no increase of labile $\mathrm{Cu}^{2+}$ was observed which suggests no spill-over of $\mathrm{Cu}$ occurred. This was corroborated by the lack of correlations between labile $\mathrm{Cu}^{2+}$ and LPO or GST. LPO was actually reduced by either $\mathrm{Cu}^{2+}$ or $\mathrm{nCuO}$ which suggests a general reduction of ROS production in tissues in mussels exposed to low concentrations of $\mathrm{Cu}$. In a previous study, exposure of mussels to nCuO could led to induction of MT suggesting that $\mathrm{Cu}^{2+}$ was released or that ROS production increased 
(Gomes et al., 2011). Indeed, both forms of $\mathrm{Cu}$ was able to induce MT in the Mediterranean mussels which suggests that $\mathrm{nCuO}$ is instable in cells and releases ionic $\mathrm{Cu}$ in the process. However, the toxicity of $\mathrm{nCuO}$ differed from $\mathrm{Cu}^{2+}$ in mussels in this study.

Table 2: Correlation analysis of biomarker data

\begin{tabular}{|c|c|c|c|c|c|c|c|c|c|c|c|}
\hline & CF & SFT & $\begin{array}{c}\text { Air } \\
\text { survival }\end{array}$ & $\begin{array}{c}\text { Weight } \\
\text { loss }\end{array}$ & LPO & DNA & COX & UB & AChE & GST & $\mathrm{Cu}^{2+}$ \\
\hline SFT & -0.13 & 1 & & & & & & & & & \\
\hline $\begin{array}{c}\text { Air } \\
\text { Survival }\end{array}$ & -0.25 & 0.08 & 1 & & & & & & & & \\
\hline $\begin{array}{c}\text { Weight } \\
\text { loss }\end{array}$ & 0.01 & -0.27 & $\mathbf{- 0 . 5 9}$ & 1 & & & & & & & \\
\hline LPO & 0.07 & $\mathbf{0 . 3 2}$ & 0.15 & -0.08 & 1 & & & & & & \\
\hline DNA & -0.06 & 0.07 & 0.15 & 0.09 & 0.03 & 1 & & & & & \\
\hline COX & $\mathbf{- 0 . 3 2}$ & -0.22 & 0.1 & 0.18 & $-\mathbf{0 . 3 3}$ & 0.16 & 1 & & & & \\
\hline UB & -0.23 & -0.04 & -0.05 & 0.12 & -0.1 & 0.01 & $\mathbf{0 . 6 1}$ & 1 & & & \\
\hline AChE & -0.01 & -0.12 & -0.04 & 0.03 & -0.02 & 0.17 & 0.34 & 0.03 & 1 & & \\
\hline GST & 0.1 & $-\mathbf{0 . 3}$ & -0.03 & -0.11 & -0.25 & -0.23 & 0.20 & 0.01 & $\mathbf{0 . 5 9}$ & 1 & \\
\hline Cu2+ & 0.03 & -0.13 & -0.09 & -0.02 & 0.07 & 0.03 & 0.09 & 0.06 & -0.1 & 0.1 & 1 \\
\hline $\begin{array}{c}\text { Total } \\
\text { Cu }\end{array}$ & -0.18 & 0.17 & -0.11 & -0.11 & $\mathbf{0 . 4 8}$ & $\mathbf{- 0 . 3 4}$ & 0.08 & 0.08 & -0.1 & -0.2 & 0.01 \\
\hline
\end{tabular}

Significant correlations are indicated in bold

According to the discriminant function analysis data, the toxicity of $\mathrm{nCuO}$ differed from those of $\mathrm{Cu}^{2+}$ and controls. This is especially of interest since the observed effects occurred without any changes in total $\mathrm{Cu}$ loadings in mussel tissues. Indeed, proteinubiquitin levels and COX activity were specifically influenced by $\mathrm{nCuO}$ but not by $\mathrm{Cu}^{2+}$, which suggest that nanoparticles were more specifically linked to the inflammatory and protein turnover (proteasome-ubiquitin protein removal) pathways. Interestingly protein-ubiquitin levels were significantly correlated with COX activity ( $\mathrm{r}=0.61$ ) which suggests that these endpoints were not only specific to $\mathrm{nCuO}$ but related with each other. A transcriptomic analysis was performed in blue mussels exposed to $\mathrm{nCuO}$ and revealed similar effects with $\mathrm{Cu}^{2+}$ although some specific changes with $\mathrm{nCuO}$ were observed (Châtel et al., 2018). Indeed, nCuO produced stronger changes in genes involved in protein assembly-disassembly, reaction oxygen species removal (potentially from COX activity), metallothionein $\left(\mathrm{Cu}^{2+}\right.$ sequestration) and energy production (ATP synthase production). The gene expression data revealed that the observed effects of $\mathrm{nCuO}$ exposure could not be explained by the release of $\mathrm{Cu}^{2+}$. A comparative study of the effects of $\mathrm{nCuO}$ and $\mathrm{Cu}^{2+}$ on the Mediterranean mussel Mytulis galloprovincialis revealed similar and other changes at the proteomic level (Gomes et al., 2014). Nanoparticulate $\mathrm{Cu}$ produced marked effects on GST (oxidative stress), protein degradation (cathepsin L) and apoptosis while $\mathrm{Cu}^{2+}$ affected hemocyte proteins involved in motility and adhesion and precollagen D which could be involved in inflammation. This study also concluded that the toxicity of nCuO was not solely due to $\mathrm{Cu}^{2+}$. The effects of $\mathrm{nCuO}$ and $\mathrm{Cu}^{2+}$ to the immune system were also reported in mussel hemocytes (Katsumiti et al., 2018). Increased phagocytosis and reactive oxygen species production were induced only by $\mathrm{nCuO}$ which suggest a "particle effect" and inflammation. In marine mussels exposed to $\mathrm{nCuO}$ and $\mathrm{Cu}^{2+}$, the 
latter caused significant $\mathrm{Cu}$ accumulation in gills and the hemolymph (Torres-Duarte et al., 2019). Although nCuO did not cause accumulation of $\mathrm{Cu}$ in tissues, damage to gill tissues and ingestion by hemocyte were observed. Decreased phagocytosis of pathogenic bacteria Vibrio tubiashii was also observed in hemocytes which could render them more susceptible to bacterial infection. Inflammation and decreased AChE activity in muscle in fish chronically exposed to (1-3 $\mathrm{mg} / \mathrm{L}$ ) nCuO was observed (Mani et al., 2019). Decreased AChE was also observed in the mussel Mytilus galloprovincialis to $10 \mu \mathrm{g} / \mathrm{L}$ for 15 days (Gomes et al., 2011). AChE activity was also reduced in mussels exposed to 10 $\mu \mathrm{g} / \mathrm{L} \mathrm{Cu}^{2+}$ which suggests that the effects were mediated, at least in part, by dissolved $\mathrm{Cu}$. Decreased AChE activity was also observed at the highest concentration $(500 \mu \mathrm{g} / \mathrm{L})$ of $\mathrm{nCuO}$ in the present study. This suggests that neuromuscular activity could be affected by the nanoparticles perhaps through interference at the protein (F-actin) assembly-disassembly level.

Another specific effect of $\mathrm{nCuO}$ that was not observed with dissolved $\mathrm{Cu}^{2+}$, in addition with COX activity, was ubiquitin tagging of proteins which suggest increased turnover of damaged proteins. Moreover, proteinubiquitin levels were significantly correlated with COX activity indicating that the damage also involved inflammation. The specific effect (nanoparticle but not the dissolved component) was also observed in freshwater mussels Elliptio complanata exposed to nanosilver (Gagné et al., 2013). Increased protein ubiquitinylation was also observed in marine mussels Mytilus galloprovincialis exposed to iron oxide nanoparticles (Taze et al., 2016). In addition to this specific effect, increased LPO and DNA damage were also observed. This suggests that metallic and oxide nanoparticles could alter the dynamic space of proteins where denatured proteins are tagged by ubiquitin for elimination via autophagosomes. Altered proteins aggregates, which are composed of ubiquitinylated proteins (synuclein), lead to the formation of Lewy bodies in the brain of zebrafish larvae exposed to titanium dioxide nanoparticles $\mathrm{CHu}$ et al., 2017). The formation and accumulation of Lewy bodies are often observed in neurodegenerative disease such as Parkinson's disease. Increased protein aggregation was recently observed in mussel exposed to "inert" polystyrene nanoparticles which was associated with changes in the fractal organization of cytoplasmic proteins (Auclair et al., 2020). This is consistent with the notion that nanoparticles contaminate the space domain of macromolecules, which can change the cytoplasmic organization in cells. Ubiquitin could also form a corona on various inorganic nanoparticles and contribute to the alteration of this signaling pathway in protein removal and turnover (Duran et al., 2015). A distinct protein-corona structure at the surface of the nanoparticles was shown to influence resulting effects such as oxidative stress, inflammation, endocytosis and cytotoxicity. This is keeping with studies showing specific toxicity of $\mathrm{nCuO}$ that were not explained by $\mathrm{Cu}^{2+}$ (Sun et al., 2017). Nanoparticles could exacerbate the production of reactive oxygen species leading to inflammation, altered protein conformation and cytotoxicity compared to the equivalent dissolved ions counterpart.

\section{Conclusion}

The bioaccumulation and toxicity of $\mathrm{nCuO}$ and $\mathrm{Cu}^{2+}$ were investigated in freshwater mussel. 
Mussels exposed to dissolved $\mathrm{Cu}^{2+}$ accumulated $\mathrm{Cu}$ in tissues but not with $\mathrm{nCuO}$ exposed mussels. On the one hand, both forms of $\mathrm{Cu}$ cause similar changes in DNA strand breaks, LPO and AChE activity. On the other hand, even though accumulation of $\mathrm{Cu}$ was not observed in mussels exposed to low concentrations of $\mathrm{nCuO}$, specific effects were observed at the inflammation and proteinubiquitin levels. The null hypothesis that $\mathrm{Cu}$ toxicity is the same for nanoparticulate and dissolved Cd is therefore rejected.

\section{Acknowledgement}

This work was funded by the Chemical Management Plan of Environment and Climate Change Canada. We thank the technical assistance of J. Kowalcyk for performing the tissue preparation and biomarker analyses and H.-P. Poirier-Richard for $\mathrm{Cu}$ analysis in mussel tissues.

\section{References}

Amiard JC, Amiard-Triquet C, Barka S, Pellerin J and Rainbow PS. (2006) Metallothioneins in aquatic invertebrates: Their role in metal detoxification and their use as biomarkers. Aquat. Toxicol. 76: 160-202.

APHA (American Public Health Association). (2010) Standard methods for the examination of water and wastewater. $17^{\text {th }}$ Edition. Washington DC, United States. http://hdl.handle.net/1969.3/24401

Auclair J, Turcotte P, Gagnon C, Peyrot C, Wilkinson KJ and Gagné F. (2019) The influence of surface coatings on the toxicity of silver nanoparticle in rainbow trout. Comp. Biochem. Physiol. C Toxicol Pharmacol. 226: 108623.

Auclair J, Peyrot C, Wilkinson KJ and Gagné F. (2020) An investigation of the biophysical effects of polystyrene nanoparticles to Elliptio complanata mussels. Environ. Sc. Poll. Res. (In press).

Bester MJ, Potgieter HC and Vermaak WJH. (1994) Cholate and $\mathrm{pH}$ reduce interference by SDS in the determination of DNA with Hoescht. Anal. Biochem. 223: 299-305.

Boryslawskyj M, Garrood AC, Pearson JT and Woodhead D. (1988) Elevation of glutathione-S-transferase activity as a stress response to organochlorine compounds, in the freshwater mussel, Sphaerium corneum. Marine Environ. Res. 24:101-104.

Bradford MM. (1976) A rapid and sensitive method for the quantitation of microgram quantities of protein utilizing the principle of protein-dye binding. Anal. Biochem. 72: 248-254.

Canesi L, Ciacci C, Fabbri R, Marcomini A, Pojana G and Gallo G. (2012) Bivalve molluscs as a unique target group for nanoparticle toxicity. Marine Environ. Res. 76:16-21.

Châtel A, Lièvre C, Barrick A, Bruneau M and Mouneyrac C. (2018) Transcriptomic approach: A promising tool for rapid screening nanomaterial-mediated toxicity in the marine bivalve Mytilus edulisApplication to copper oxide nanoparticles. Comp Biochem. Physiol. C Toxicol. Pharmacol. 205: 26-33.

Durán N, Silveira CP, Durán M and Martinez DS. (2015) Silver nanoparticle protein corona and toxicity: a mini-review. J. Nanobiotechnol. 13: 55. https://doi.org/10.1186/s12951-015-0114-4

Farrell RA, McArdle HJ and Camakaris J. (1993) Effects of metallothionein on the observed copper distribution in cell extracts. J. Inorg. Biochem. 49: 9-22.

Gagné F, Gagnon C and Blaise C. (2007) Aquatic Nanotoxicology: A review. Current Topics Toxicol. 4: 51-64.

Gagné F, Auclair J, Turcotte P, Fournier M, Gagnon C, Sauvé S and Blaise C. (2008) Ecotoxicity of CdTe quantum dots to freshwater mussels: impacts on immune system, oxidative stress and genotoxicity. Aquat. Toxicol. 86: 333-340.

Gagné F, André C, Skirrow R, Gélinas M, Auclair J, Van AggelenG, Turcotte P and Gagnon C. (2012) Toxicity of silver nanoparticles to rainbow trout: A toxicogenomic approach. Chemosphere 89: 615-622.

Gagné F, Auclair J, Turcotte P and Gagnon C. (2013) Sublethal effects of silver nanoparticles and dissolved silver in freshwater mussels. J. Toxicol. Environ. Health A 76: 479-490.

Gagné F. (2014) Biomarkers of infection and diseases. Biochemical Ecotoxicology- Principles and Methods. Chapter 11, First Edition Elsevier Inc., USA.

Gagné F, Auclair J, Peyrot C and Wilkinson KJ. (2015) The influence of zinc chloride and zinc oxide nanoparticles on air-time survival in freshwater mussels. Comp. Biochem. Physiol. 172-173C: 36-44.

Gélinas M, Lajeunesse A, Gagnon C and Gagné F. (2013) Temporal and seasonal variation in 
acetylcholinesterase activity and glutathione-Stransferase in amphipods collected in mats of Lyngbya wollei in the St-Lawrence River (Canada). Ecotoxicol. Environ. Saf. 94: 54-59.

Gomes T, Pinheiro JP, Cancio I, Pereira CG, Cardoso C and Bebianno MJ. 2011. Effects of copper nanoparticles exposure in the mussel Mytilus galloprovincialis. Environ. Sci. Technol. 45: 9356-9362.

Gomes T, Chora S, Pereira CG, Cardoso C and Bebianno MJ. (2014) Proteomic response of mussels Mytilus galloprovincialis exposed to $\mathrm{CuO}$ NPs and $\mathrm{Cu}^{2+}$ : an exploratory biomarker discovery. Aquat. Toxicol. 155: 327-336.

Hanna SK, Miller RJ and Lenihan HS. (2014) Accumulation and toxicity of copper oxide engineered nanoparticles in a marine mussel. Nanomaterials (Basel) 4: 535-547.

Hu Q, Guo F, Zhao F and Fu Z. (2017) Effects of titanium dioxide nanoparticles exposure on parkinsonism in zebrafish larvae and PC12. Chemosphere 173: 373-379.

Katsumiti A, Thorley AJ, Arostegui I, Reip P, ValsamiJones E and Tetley TD, Cajaraville MP. (2018) Cytotoxicity and cellular mechanisms of toxicity of CuO NPs in mussel cells in vitro and comparative sensitivity with human cells. Toxicol. In Vitro 48: 146-158.

Mani R, Balasubramanian S, Raghunath A and Perumal E. (2019) Chronic exposure to copper oxide nanoparticles causes muscle toxicity in adult zebrafish. Environ. Sci. Poll. Res. https://doi.org/10.1007/s11356-019-06095-w

Moëzzi F, Hedayati SA and Ghadermarzi A. (2019) Copper bioaccumulation kinetics in swan mussel, Anodonta cygnea (Linnaeus, 1758) during waterborne exposure to $\mathrm{CuO}$ nanoparticles. Bull. Environ. Contam. Toxicol. 102: 46-51.

Olive PL. (1988) DNA precipitation assay: a rapid and simple method for detecting DNA damage in mammalian cells. Environ. Mol. Mutagen. 11: 487-495.
Rajput V, Minkina T, Ahmed B, Sushkova S, Singh R, Soldatov M, Laratte B, Fedorenko A, Mandzhieva S, Blicharska E, Musarrat J, Saquib Q, Flieger J and Gorovtsov A. (2020) Interaction of copper-based nanoparticles to soil, terrestrial, and aquatic systems: Critical review of the state of the science and future perspectives. Rev. Environ. Contam. Toxicol. 252: 51-96.

Rather MA, Bhat IA, Sharma N and Sharma R. (2018) Molecular and cellular toxicology of nanomaterials with related to aquatic organisms. Adv. Exp. Med. Biol. 1048: 263-284.

Sun X, Chen B, Bin Xia, Han Q, Zhu L and Qu K. (2017) Are $\mathrm{CuO}$ nanoparticles effects on hemocytes of the marine scallop (Chlamys farreri) caused by particles and/or corresponding released ions? Ecotoxicol. Environ. Saf. 139: 65-72.

Udhayakumaria D, Velmathia S, Sungb YM and Wu SP. (2014) Highly fluorescent probe for copper (II) ion based on commercially available compounds and live cell imaging. Sensors Actuators B 198: 285-293.

Taze C, Panetas I, Kalogiannis S, Feidantsis K, Gallios GP, Kastrinaki G, Konstandopoulos AG, Václavíková M, Ivanicova L and Kaloyianni M. (2016) Toxicity assessment and comparison between two types of iron oxide nanoparticles in Mytilus galloprovincialis. Aquat. Toxicol. 172: 9-20.

Torres-Duarte C, Hutton S, Vines C, Moore J and Cherr GN. (2019) Effects of soluble copper and copper oxide nanoparticle exposure on the immune system of mussels, Mytilus galloprovincialis. Environ. Toxicol. 34: 294-302.

Wills ED. (1987) Evaluation of lipid peroxidation in lipids and biological membranes. In: Biochemical toxicology: A practical approach. (Eds.) Snell K., Mullock B., Washington D.C: IRL Press; p. 127-50. 